\title{
DNA Repair Protein RAD51 Homolog 4
}

National Cancer Institute

\section{Source}

National Cancer Institute. DNA Repair Protein RAD51 Homolog 4. NCI Thesaurus. Code C116932.

DNA repair protein RAD51 homolog 4 (328 aa, $~ 35 \mathrm{kDa}$ ) is encoded by the human RAD51D gene. This protein plays a role in homologous recombination repair. 